KUINKA IHMISELÄMÄ MULLISTUU HILJAISESTI SILMIEMME ALLA

Kaisa Kuurne, VTT, dos., Itä-Suomen yliopisto

Ilpo Helén: Elämän politiikat. Tutkijaliitto, Helsinki. 2016, 401 s.

Ilpo Helénin teos "Elämän politiikat" johdattaa suomalaiset lukijat Michel Foucault'n ajatteluun ja biopolitiikan ajatukseen suomalaisten yhteiskunnallisten käytäntöjen kannalta relevantilla tavalla. Teos on selkeästi jäsennelty, hyvin kirjoitettu ja avautuu siten näkökulmaan vihkiytyneitä laajemmallekin yleisölle. Helén kääntää biopolitiikan elämän politiikaksi, perspektiiviksi, jonka välityksellä voimme lähestyä aikamme tärkeitä kysymyksiä historiallisina. Kirja esittelee ja erittelee näkökulmaan liittyviä käsitteitä, joita havainnollistetaan erilaisin esimerkein suomalaisen yhteiskunnan ja hyvinvointijärjestelmän käytännöistä. Itse olen käyttänyt kirjaa sosiaalitieteiden opetuksessa erityisesti hyvinvoinnin käytäntöjen historiallisessa ja kriittisessä tarkastelussa. Painotan tässä arviossa erityisen hyödyllisiksi katsomiani näkökulmia ja käsitteitä, jotka soveltuvat mitä moninaisempien yhteiskunnallisten käytäntöjen ja tapahtumien tarkasteluun.

Elämän politiikan näkökulma kutsuu huomiomme tapahtumiseen. Sen keskeisiä tekijöitä ovat ongelman muotoutumiset, käytännöt ja asetelmat, joihin elämän politiikka ilmaantuu, joissa se muuttaa muotoaan ja joihin se vaikut- taa. Elämän politiikka kohdistuu eläviin ja näiden elämään. Helén esittää elämän politiikan avaavana käsitteenä, joka tekee mahdolliseksi oman aikamme ajattelun ymmärtämisen ja tulkitsemisen historiallisesta perspektiivistä. Elämän politiikan näkökulma liittää asioiden, tapahtumien ja muutosten merkityksen tai arvon uuteen asiayhteyteen, mikä asettaa sen kriittiseen valoon arvioiden tai määritellen sen uudelleen. Näin näkökulma mahdollistaa luonnollisina tai tavallisina näyttäytyvien käytäntöjen itsestäänselvyyden tai "luonnollisuuden" taakse ja toisin näkemisen.

Kirja keskittyy ennen muuta nk. affirmatiiviseen politiikkaan, jossa ihmiselämää valvotaan ja vaalitaan ihmisten arjessa ja instituutioiden käytännöissä. Se on hienovaraista elämän politiikkaa, joka ei ehkä näyttäydy dramaattisena, mutta Helénin mukaan vaikuttaa ihmisten elämään eniten. Mielestäni tämä valinta perusteltu ja auttaa tarkastelemaan arjen "pieniä" käytäntöjä kriittisesti. Elämän politiikan aiheita ja aineksia käsitellään väestöstä yksilöihin, soluihin ja molekyyleihin.

Elämän politiikan muodoista esiin nostetaan tiedon muodot ja teknologiat, joissa normaalin ja riskin käsitteet ovat keskeisiä. Biopolitiikka esitetään elämän vaalimisena ja paimentamisena, mutta myös väestöllisten, yhteiskunnallisten, taloudellisten ja psykologisten prosessien ohjaamisena ja vauhdittamisena. Koska tieto elävistä kiinnittyy keinoihin ja tekniikoihin, Helén puhuu elämän politiikan tiedollisesta ulottuvuudesta teknologiana. Siinä tieto kytkeytyy elämänilmiöiden hallittaviksi tekemisen käytäntöihin, joissa käsi- 
tys normaalista muodostuu. Normaali määrittyy epänormaalin heijastumana ja vaatii jatkuvaa tulkintaa ja hallintaa liikkuessaan asiayhteydestä toiseen.

Normalisoinnin lajeista Helén nostaa ensinnäkin esiin tiedonhankinnan, johon liittyy tarkkailu, testaus ja tutkinta. Toista normalisoinnin lajia voi kutsua harjaannuttamiseksi, jossa pyritään korjaamaan vajaakykyisyyttä ja jossa arvioidaan yksilöiden edistymistä kohti normaalia. Ensimmäiseen kategoriaan kuuluvat esimerkiksi neuvola ja terveystarkastukset; toiseen kategoriaan kuntoutus, erityisopetus ja erilaiset elämänhallintaohjelmat. Tiedonhankinta normalisoinnin lajina on nykySuomessa rutiininomaista ja pyrkii esimerkiksi lasten terveyden seuraamisessa löytämään poikkeamat ja mahdolliset häiriöt mahdollisimman varhain. Harjaannuttaminen puolestaan pyrkii muuttamaan ihmisten terveyskäyttäytymistä ja näin kohentamaan jonkin ryhmän terveyttä normaaliksi. Kolmas normalisoinnin laji on itseymmärryttäminen, joka liittyy ennen muuta valistukseen, kansalaiskasvattamiseen, psykoterapeuttisiin käytäntöihin sekä ohjaavaan neuvontaan. Itseymmärryttävä normalisointi pyrkii erilaisiin terveyspoliittisiin päämääriin ihmisten elämäntapojen muuttamisen välityksellä. Normalisointia tekevät myös lääketieteelliset menetelmät, apuvälineet sekä standardointi, joka on nähtävissä esimerkiksi maailmanlaajuisissa tautiluokituksissa.

Normaaliin keskeisesti liittyvä tekijä on riski, joka liittyy tämänhetkisiin asioihin, henkilöihin tai toimintoihin, jotka voivat mahdollisesti olla "vaarallisia" tulevaisuudessa. Riski on aina ennakoiva arvio tulevaisuudesta, jossa jokin on mahdollista, odotettavaa tai todennäköistä. Riskin käsite edellyttää ajatuksen, että uhka voidaan muuntaa määriteltäväksi, laskettaviksi seikoiksi, joiden suhteen voidaan toimia. Näin riskien kalkylointiin kuuluu aina jonkinlaista hallintaa ja ennakointia. Nykymaailmassa riskien laskeminen ja tulkitseminen määrittävät keskeisesti erilaisia vakuutus- ja terveyskäytäntöjä, joissa riskikalkyyleilla ja niihin perustuvilla toimintatavoilla pyritään minimoimaan tulevaisuuden haittoja.

Kirjan normalisointiin ja riskiin liittyvät näkökulmat tekevät käsinkosketeltaviksi ne tavat, joilla yksinkertaiset ja totunnaiset käytännöt meitä ohjailevat. Opettamillani kursseilla nämä näkökulmat ovat myös saaneet opiskelijat havahtumaan siihen, miten yksilöllisiksi mielletyt elämäntapavalinnat ovat toisaalta yhteiskunnallisen säätelyn lävistämiä.

Helén käsittelee Foucault'n hallinnan käsitettä elämän politiikan yhteydessä. Tässä on kyse muun muassa ihmisten käyttäytymistä ohjaavista teknologioista ja käytännöistä sekä niihin liittyvästä järkeilystä ja sen polveutumisesta. Perspektiivissä valtiot hallinnallistuvat. Valtion mahti perustuu kykyyn ja taitoon hallita yhteiskuntaa ja sen jäseniä, jotka se onnistuu tekemään hallittaviksi. Pohjoismaisessa hyvinvointivaltiossa on lukuisa määrä hyvää tarkoittavia käytäntöjä, joissa tästä näkökulmasta katsottuna pyritään tekemään kansalaisista hallittavia eli terveitä, tuottavia ja hyvinvoivia. Helén käsittelee kaitselmusvaltiota ja onnen taloutta, 
joissa turvallisuuden, hyödyn ja onnellisuuden hallinta kohtaavat, sosiaalisia ongelmia pyritään vähentämään sekä ihmisten hyvinvointia lisäämään. Liberalistisen valtion hallitseminen on potentiaalisesti totaalista, koska valtion tehtävänä on turvata ihmiselämää ja sen luonnollista kulkua. Näin valtion on saatava kosketus jokaiseen ihmiselämän muotoon ja ilmentymään.

Helén esittelee foucault'laista nykytutkimusta, jonka näkökulmasta liberaaleissa sosiaalivaltioissa vallan harjoittaminen on yksilöllistävää eli yhteiskunnan ohjailu ja järjestys tuotetaan yksilöiden vapauden välityksellä. Näin hallinta ankkuroidaan ihmisten omiin intresseihin. Itsesäätely ja tahdon lujittaminen valjastetaan niin työttömien, päihderiippuvaisten, sairaiden kuin terveidenkin elämän parantamiseen. Hallinnan kohteiksi nousevat oma ruumis, halut, tarpeet, tunteet, haaveet, elämäntavat ja ihmissuhteet, joiden saralla valtio paimentaa kansalaisia. Näin sosiaalivaltion talous on onnen taloutta.

Yhteiskuntien liberalisoituminen tuo hallintaan uusia piirteitä. Sosiaalinen lakastuu, ja markkinoista tulee hallinnan puite ja järkeilyn kiintopiste. Uusi hallinta edellyttää ihmisiltä uudenlaista subjektiutta ja muokkaa heitä uudistumaan yksilöinä eräänlaisiksi oman elämänsä yrittäjiksi. Edistynyt liberalismi synnyttää palvelu- ja asiantuntijajärjestelmiin sisäiset markkinat, joissa kaikki toiminnot voidaan mitata rahassa. Näin tehokkuus ja taloudellinen järkeily tunkeutuvat myös julkisen palvelujärjestelmän toimintalogiikkaan.
Helénin ajattelussa talouden ja elämän politiikan sekä hyödyn ja huolenpidon yhteen sopiminen tai vastakkaisuus on historiallisesti kontingenttia ja alati muuntuvaa. Siksi se pitää aina sisällään kamppailun ja kiistan mahdollisuuden ja avaa elämän hallintaan poliittisen ulottuvuuden. Kirja käsittelee poliittisten teknologioiden uudistumista edistyneessä liberalismissa esimerkiksi laskettavuuden, arvioinnin ja tieteen näkökulmista.

Kirja nostaa esiin aikamme elämän politiikan keskeisimpänä kiintopisteenä elämän biologisena asiana, olemassaolon kysymyksenä tai elämäntapana, joka on muokattavissa. Bioteknologinen vallankumous vie huomion soluihin ja molekyyleihin. Ihmiset alkavat nähdä itsensä biologisesti muokattavina subjekteina. Helén esittää, että huipputeknologisessa biolääketieteellisessä syntynyt ajattelun ja käytäntöjen biologisen muokattavuuden maisema on noussut elämän politiikan uudeksi pontimeksi elämän itsen sijaan. Siinä käydään jatkuvia ontologisia kiistoja normaalista ja patologisesta sekä näiden välisistä suhteista. Kun kysymykset vielä suuntautuvat tulevaisuuteen kohdistuviin odotuksiin ja ennakointiin, potentiaalinen vitaalisuus ja ihmiselämä politisoituvat ennen näkemättömillä tavoilla.

Elämän manipulointi on ennaltaehkäisyä, kontrollia ja kokeilua, joka kohdistuu ennen muuta lisääntymiseen. Esimerkkinä tästä Helén nostaa sikiödiagnostiikan. Äitiyshuollon teknologisoituminen edellyttää yhä intensiivisempää kontrollia, jossa lisääntymiselämä jaotellaan aineksiin, tekijöihin ja 
vaikutussuhteisiin, joita tarkkaillaan, lasketaan, mitataan ja käsitellään. Odottava äiti joutuu jatkuvasti suhteuttamaan erilaisia terveysriskejä lääketieteellisen teknologian riskilaskelmiin sekä omiin toiveisiin ja epäilyihin tulevasta elämästä. Tässä asetelmassa odottavan äidin tulee yhtäältä vaalia tulevan lapsen hyvinvointia, mutta potentiaalisesti kyetä myös luopumaan lapsesta, jos sikiötutkimukset osoittavat vaikeaa vammaisuutta. Naisten valinnanvapaus ja eugeniikan haamut törmäilevät toisiinsa mahdottomassa asetelmassa, jossa naiselta odotetaan kyvykkyyttä arvioida riskejä ja tehdä valintoja elämästä ja kuolemasta. Vaikka julkilausutusti kyse on autonomian mahdollistamisesta, eikä lääkäreiden tule puuttua ihmisten omiin valintoihin, lääketieteellinen teknologia lisää lääkäreiden valtaa ihmisten elämään.

Helénin kirja on ensimmäinen suomalainen kokonaisesitys elämän politiikasta ja aikamme ilmiöistä, joita perspektiivin avulla voidaan tarkastella. Kirja avaa aiemmin jokseenkin sisäänpäin kääntynyttä hallinnan tutkimusta ja keskustelua laajemmalle yleisölle. Se myös antaa välineitä nähdä ja tarttua aikamme merkittäviin tapahtumiin, mitä pidän kirjan erityisenä ansiona. Elämän politiikan käsitteistä vähempikin olisi riittänyt aiheen syvälliseen tarkasteluun. Toisaalta käsitteellinen runsaus antaa monenlaisista näkökulmista ja teemoista kiinnostuneille tarttumapintaa.

Kirjan erityinen ansio on siinä, miten se auttaa näkemään ja tarttumaan ihmiselämää hiljaisesti omien silmiemme alla mullistaviin asioihin, jotka muuten jäisivät huomiotta. Näin hallinnan tut- kimus avautuu laajemmalle suomalaiselle yhteiskuntatieteelliselle yleisölle, ja sen monenlaisiin tutkimusotteisiin hyvin yhdistyvät kriittiset näkökulmat tulevat tutuiksi.

\section{VANHUSTYÖN JOHTAJA PALJON VARTIJANA}

Marjo Ring, TtM, tohtorikoulutettava, Itä-Suomen yliopisto

Sanna Laulainen, YTT, professori (ma.), Itä-Suomen yliopisto

Jenni Kulmala (toim.): Parempi vanhustyö. Menetelmiä johtamisen kehittämiseen. PS-kustannus, Jyväskylä. 2017, $228 \mathrm{~s}$.

Kirja tarttuu ajankohtaiseen ja julkista keskustelua herättäneeseen aiheeseen, vanhustyöhön. Kirjassa vanhustyön johtajat nostetaan avaintekijöiksi sekä laadukkaan vanhustyön toteuttajina että työntekijöiden hyvinvoinnin turvaajina. Kirjan tavoitteena on tarjota konkreettisia menetelmiä vanhustyön johtamisen tueksi ja sen kehittämiseksi.

Kirja koostuu kolmesta osasta, joissa vanhustyön ja johtamisen asiantuntijat nostavat esille johtamisen eri ulottuvuuksia. Ensimmäinen osa rakentaa pohjaa koko kirjan kantavalle teemalle, hyvin johdetuille asiakaslähtöisille ja yksilöllisille vanhuspalveluille. Ensimmäisen osan artikkeleissa vanhustyön johtamisesta rakennetaan oma erityinen johtamisen osa-alueensa, jonka erityisenä tavoitteena on asiakkaan elämän- 